\title{
THE RELATIONSHIP BETWEEN STRATEGIC MANAGEMENT AND PUBLIC RELATIONS AND THEIR IMPLICATIONS FOR FINANCIAL OPERATIONS
}

\author{
RABRENOVIC D. Mihajloํ, MITROVIC Ranka ${ }^{2}$, KOVACEVIC Boban ${ }^{3}$ \\ ${ }^{I}$ Faculty of Business Economics and Entrepreneurship, Belgrade (SERBIA) \\ ${ }^{2}$ Faculty of Business Studies, Belgrade (SERBIA) \\ ${ }^{3}$ Radio-Television of Serbia, Belgrade (SERBIA) \\ Email: mihajlo.rabrenovic.011@gmail.com
}

\begin{abstract}
In this paper, the co-authors have addressed the relationship between strategic management and public relations, and their implications for financial operations. In addition to growth and development, financial results of an organization are the focus of a business plan implemented by the director general (strategic manager), and as a rule, they represent the hierarchical link between the public relations service and other services affecting financial operations. The lack of appropriate internal communication and coordination of this "triangle," which is a common occurrence in practice, adversely affects financial results.

In this paper, explanations of their mutual relations in the above "triangle" with certain recommendations shed some light on multidimensional frameworks of modern business, in which heterogeneous, renaissance knowledge and experiences are required, on the application of which the outcomes of overall, and especially financial business depend.

For the aforementioned reasons, in addition to aligning the organization with the environment, strategic managers also have in their portfolio of activities the internal alignment of individual teams, whose synergy contributes to the achievement of the vision, mission, and strategic goals.
\end{abstract}

Keywords: strategic management, public relations, financial results, director general

JEL: $L 10$

UDC: $005.52: 336.005 .332: 659.231$

COBISS.SR-ID: 18172681

\section{Introduction}

Contemporary financial operations of organizations are the result of understanding heterogeneous, renaissance knowledge and experiences, which are mutually intertwined and complementary. The umbrella discipline, which brings together the various specialties of the complex world in which organizations operate, is strategic management, and it finds application from small entrepreneurial ventures to multinational global companies. Depending on the nature of the business, teams of different specialties are formed within the organization, and the outsourcing of certain resources is possible if necessary, using the "make or buy decision" model. According to Chandler's view that the organizational structure monitors the implementation of the strategy in achieving the goals, organizations opt for the appropriate structural modalities when it comes to the necessary tasks related to public relations, as well as those related to financial operations and reporting. Harmonizing the relationship between these activities is one of the keys to success. 
By structure, in addition to the introduction and conclusion, the paper has three subunits:

1. Public relations in a globalized world; 2. Contemporary challenges of strategic management, and 3. Financial operations parameters and company image.

\section{Public Relations in a Globalized World}

The process of globalization has brought people, economies and cultures together, and has contributed the most to the free flow of goods and services. National economies have recognized the importance of engaging in global flows of capital and ideals. In parallel with this trend, "the integration of national economies into global markets has led to the privatization of public operations and the reduction of direct state participation in the traditional trade activities of public services" [1]. The efforts taken to realize strategies would not be possible without the active involvement of the public relations sector, regardless of what business the company is engaged in. "Although the basic goal of public relations is the same, regardless of whether it is about activity in the business, political, cultural, sports, or humanitarian field, the models of organizing PR can be quite different" [2].

Identifying business diversity is critical for deciding where and how a company wants to get involved in the market. "Multinationally oriented companies apply a regiocentric orientation in business, i.e., operate in regional parts of the world market. Globally oriented companies apply geocentric business orientation, i.e., operate in the global market" [3]. In an era where everything local becomes global and vice versa, it is crucial to determine a positioning strategy. "For each segment that a company follows, a product positioning strategy must be created. It can be assumed that any competing product in circulation occupies a certain place in the market segment" [4].

Being different in the market, creating certain actions is primarily a task of the public relations (PR) sector. It is necessary to identify the target group, the market, and highlight all the peculiarities and differences between companies and products. For, "the totality of all attributes that an individual (or target group) recognizes (or imagines) when facing a company's name, sign, or product, i.e., the sum of all the characteristics that separate one organization from others in the market, forms its corporate identity" [2], which brings competitive advantage. Therefore, it is precisely this corporate identity that determines the strategy of positioning the company with respect to the intended target public, which it addresses, and what channels of communication it will choose, thus, "the organization uses the media as the primary means of transmitting messages sent to the target public. That is why an organization needs to establish and maintain good media relations" [5].

Today, the media are a bridge for connecting with modern consumers. It is necessary to develop adequate PR actions that will constantly remind customers of the product or service the company distributes. "Practice shows that the success of any more ambitious PR action depends greatly on knowing the characteristics of the target public and its segments. This task is not easy at all since the potential audience does not include only the buyers (or service users), but much more sophisticated groups which consist of suppliers, distributors, carriers, wholesalers and their advisers" [2]. Traditional media such as print, radio and television represent only one part of the communication spectrum of activity in the media sphere. The decisive role was taken by the Internet. "The Web has changed the rules. If you continue to follow traditional public relations techniques, I am sure you will realize that they have no effect anymore" [6]. With the development of new technologies, there have been advances in PR techniques and modes of presentation. "In the new e-market of ideas, organizations are emphasizing their expertise in different ways, such as great web locations, podcasts, blogs, ebooks and online press releases that address customer needs" (Scott, 2009). Also, companies 
present their comparative advantages on the increasingly popular social networks, all in support of strategic management activities.

\section{Contemporary Challenges of Strategic Management}

The literature has debated whether and to what extent public relations are part of strategic management itself. Whatever the conclusion, the fact is that "contemporary societies require public relations professionals who can handle global interactions, relationships and responsibilities, and who can manage relations between organizations and stakeholders in a globalized, digitized world where issues and crises are becoming commonplace in terms of mismanagement of organizations" [7].

Strategic managers, in addition to considering their current position, are focused on the medium- and long-term plan, and so view their customers as having a "degree of inclination to present satisfaction regarding the same satisfaction in the future" [8]. In this context, the role of public relations managers is significant in that they adequately present certain phenomena in the internal and external public, which ultimately affects perception.

Among the contemporary challenges of strategic management, the inadequate implementation of the formulated strategy particularly stands out. In general, certain influences that come from the external environment can have a negative effect on an organization's operations. Rapid and dynamic, and often unexpected, changes in technology, social developments, as well as financial and other risks contribute to the raising of questions, which often cannot be easily answered in an adequate and timely manner.

More than ever, the strategic management employees in their actions take into account individual consumer preferences, which ought to be the focus of attention since they make the decision "whether to consume certain goods or not" [8]. Given that there is a variety of risks in contemporary business, organizations often choose to conclude appropriate insurance contracts where possible [9].

\section{Financial Operations Parameters and Company Image}

The image as a complete picture of the company's business is crucial for the effectiveness of strategic management.

In the turbulent and changing environment, as it is today, the primacy of business lies in mastering and controlling relevant information, while simultaneously sublimating and integrating the goals of different stakeholders of the company. Every company that wants to operate effectively and efficiently needs to adopt and implement this mindset. Thomas A. Stewart points out: "Information and knowledge are the thermonuclear competitive weapon of our time." Therefore, the importance of having the right information to operate effectively is essential [10].

The company needs to satisfy the interests of a wide range of heterogeneous groups: customers, suppliers, creditors and many others. Therefore, a negative image of a company that appears in public can have negative repercussions on a business manifested in a decline in the value of business indicators and vice versa. Due to the appearance of a negative image of the company's business, the aforementioned stakeholders withdraw. This situation is followed by competitors who are stalking the business of other companies in the same industry, and who can take advantage of the company's poor image and attract customers to themselves.

In such situations, efficiency in decision-making of top management is very important.

Responding promptly to information sent through the media can save a company from a significant drop in sales revenue, and even from making losses. 
Contemporary business conditions have imposed a new stage in business reporting. There is a need to apply new forms of reporting, as a comprehensive tool for communication with stakeholders. On the other hand, presenting the company's intentions and goals as defined by the business strategy, and presenting key business indicators can enhance the company's image in the capital market. A holistic and integrative reporting approach that incorporates several dimensions of a company's business is a brilliant example of the new business and reporting technique used to increase the company's visibility in the eyes of customers.

However, in day-to-day business, looking through the prism of strategic management and its relationship with the financial aspects of the company's operations, indicators can be identified which are an adequate measure of reflecting company information in the public (Customized: Cherian and others): sales volume, return on equity, return on assets, amount of revenue, collectability of receivables, negotiation and pricing policies with suppliers, operating expenses, interest rates with creditors, and more.

Financial reporting is the process of presenting financial data in different forms of reports, both traditional and contemporary, and does not have a single unified goal, but rather a goal derived from the needs of different stakeholders, whether internal or external users. Further, financial information and the use of reports based on them are directly reflected in the reduction of uncertainty and risk in making business decisions.

By providing extremely valuable financial and accounting information, it seems quite clear that financial reporting contributes not only to the rational decision-making of its users, but also to the strengthening of the financial system, the increased use of financial statements, and, in general, the building of trust and security in business communication [11].

In this regard, it is necessary to create a legal framework, as well as climate in which the creators of these reports will consistently and unambiguously present information that reflects actual transactions in the company, minimize the need for tax evasion of entities, by applying the effects of overestimating or underestimating certain balance sheet items, presenting unrealistic costs, and other elements.

The value of a corporate brand and reputation brings to the company benefits that in the long run increase the company's financial performance and market value [12]. In other words, the higher value of companies, which is reflected in the positive image of the company, increases sales and increases the return on invested capital, which leads to the achievement of competitive advantage and vice versa.

The relationship between strategic management, company image, and financial performance is not a new issue, but theorists and practitioners are looking for new mechanisms to regulate their relationships. Disclosing the business of now already textbook examples of Enron and WorldCom companies, establishing the Corporate Governance Code as well as the OECD Principles, draws attention to the close relationship between establishing the company and stakeholder relations, as well as creating true, continuous and credible business information. It is a well-known fact that today in the era of globalization and digitalization, customer preferences are constantly changing, which has a direct impact on investments in new products, new services, new forms of marketing and advertising to reach as many customers as possible before the competition, as well as to occupy a larger market share. A business understood in this way will enhance the synergy of action and joint decision-making within the company.

\section{Conclusion}

The above considerations indicate that if there is continuous communication between strategic management, public relations and financial operations, the financial performance of the business will serve the identified strategies of target customers, revenue, market share, and 
return on equity. In other words, to achieve these goals, it is necessary to ensure continuous maintenance of relations with all interest groups, and, above all, with customers who are extremely sensitive to company information and the amount of representation of companies in the media through various forms of advertising.

To present oneself in the modern business world, to be different, is an axiom. The positioning of products and services in consumer awareness is the key task of the public relations sector. The choice of communication channels and the way of sending messages to the target public significantly influences the financial aspect of companies' operations. Also, the media are the ones that represent the bridge for connecting with customers, and more recently the global network - the Internet - is taking over the main role in the media sphere.

Companies that have a well-established customer relationship system have better financial performance than companies that do not create a strong relationship and communication with them, and strategic management contributes by looking at the internal and external environment and taking appropriate measures and activities.

\section{REFERENCES}

[1] Rabrenović M. (2011). Strategijski menadžment u javnom sektoru (Strategic Management in the Public Sector). Beograd: Službeni glasnik, p. 150.

[2] Pavlović M., Aleksić M. (2011) Odnosi s javnošću (Public Relations). Beograd: Megatrend univerzitet, pp. 38-56-86.

[3] Milanović-Golubović V. (2009). Međunarodni marketing i globalni biznis (International Marketing and Global Business). Beograd: Megatrend univerzitet, p. 32.

[4] Kotler F. (1988). Upravljanje marketingom 1 (Marketing Management 1). Zagreb: Informator, p. 278.

[5] Bazić A. (2015). Uticaj masovnih medija na imidž organizacije (The Influence of Mass Media on an Organization's Image). Beograd: Godišnjak Fakulteta za medije i kulturu-Komunikacije, mediji, kultura: p. 356.

[6] Skot Meriman. D. (2009). Nova pravila marketniga i odnosa s javnošću: kako koristiti sopštenja za javnost, blogove, potkast, viralni marketing i medije na internetu kako biste direktno doprli do kupca (The New Rules of Marketing and PR: How to Use News Releases, Blogs, Podcasting, Viral Marketing and Online Media to Reach Buyers Directly). Beograd: Mikro knjiga, pp. 34-195.

[7] Grunig E. James (2011) Public relations and strategic management: Institutionalizing organization public relationships in contemporary society, Central European Journal of Communication 1, p. 11

[8] Krstić, M. (2014). Rational choice theory and addiction behavior. Market-Tržište, 26(2), pp. 163-177.

[9] Jovanović S. (2007) Premija osiguranja neživotnih grana (Non-life Insurance Premium), Revija za pravo osiguranja, 4 , str. 28

[10] Dragičević, Mitrović, Mikuljević (2012) Participativno odlučivanje i korporativno izveštavanje u kreiranju novih okvira korporativnog upravljanja (Participatory Decision-Making and Corporate Reporting in Creating New Corporate Management Frameworks), Megatrend revija, 2012, str.186.

[11] Krstić, J., Đorđević, M. (2013): Reafirmacija primene etičkih principa u procesu finansijskog izveštavanja - potreba u kriznom i postkriznom period (Reaffirming the Application of Ethical Principles in the Financial Reporting Process - Needs in Crisis and Post-Crisis Periods), Tematski zbornik: Antikrizne politike i postkrizni procesi: Izazovi ekonomske nauke, Ekonomski fakultet Univerziteta u Nišu, str. 667.

[12] Roberts, P., \& Dowling, G. (2002). Corporate reputation and sustained superior financial performance. Strategic Management Journal, 23(12), pp. 1077-1093.

\section{Article history:}

Received 25 May 2020

Accepted 28 Juny 2020 